\title{
Comportamento eleitoral nas eleições suplementares para prefeito no Brasil (2013-2015)
}

\section{The electoral behavior in supplementary mayoral elections in Brazil (2013-2015)}

\section{Comportamiento electoral en las elecciones complementarias para alcalde en Brasil (2013-2015)}

\author{
iD (9) Alvaro Augusto de Borba Barreto \\ Universidade Federal de Pelotas, Pelotas, Rio Grande do Sul, Brasil \\ albarret.sul@gmail.com \\ (iD) 9

\section{Bruno Souza Garcia} \\ Universidade Federal de Pelotas, Pelotas, Rio Grande do Sul, Brasil \\ br.sgarcia@hotmail.com
}

\begin{abstract}
Resumo: O artigo aborda as 113 eleições suplementares para prefeito, realizadas no Brasil, no período 2013-2015, com a intenção de analisar o comportamento dos eleitores. Compara os índices de abstenção, de votos inválidos (em branco e nulos) com os da disputa anulada para verificar se a disposição do eleitorado se manteve ou se alterou, assim como apreciar de que modo se deram as eventuais mudanças. Os resultados indicam o aumento da abstenção e dos votos nulos, mas a redução dos votos inválidos e dos em branco. As fontes principais são o Tribunal Superior Eleitoral (TSE) e o portal G1, para obter as informações sobre os resultados dos pleitos.
\end{abstract}

Palavras-chave: Eleição suplementar. Abstenção. Voto inválido.Voto em branco. Voto nulo.

Abstract: The article covers the 113 supplementary mayoral elections, conducted in Brazil in the period 2013-2015, with the intention to analyze 
the behavior of the voters. Compares the abstention index, invalid votes, blank and null with the annulled contention to determine whether the disposition of the electorate remained stable or changed, as well as appreciate how it gave any changes. The results indicate an increase in abstention and null votes, but the reduction of invalid and blank votes. The main sources are the Superior Electoral Court and the G1 portal, to obtain information about the results of elections.

Keywords: Supplementary election. Abstention. Invalid vote. Blank vote. Null vote.

Resumen: El artículo analiza las 113 elecciones complementaras para alcalde, celebradas en Brasil, en el período 2013-2015, con la intención de analizar el comportamiento de los votantes. Compara las tasas de abstención, los votos inválidos, los votos en blanco y los nulos con los de la disputa anulada para ver si se ha mantenido o cambiado la disposición del electorado, así como para ver cómo se han producido los cambios. Los resultados indican un aumento en la abstención y votos nulos, pero la reducción de los votos inválidos y en blanco. Las fuentes principales son el Tribunal Superior Electoral y el portal G1, para obtener las informaciones sobre los resultados de las disputas.

Palabras clave: Elección suplementaria. Abstención. Voto inválido. Voto en blanco. Voto nulo.

Data de recebimento do artigo: 26/10/2018

Data de aprovação do artigo: 20/09/2019 


\section{Introdução}

Como o eleitor se comporta quando a sua decisão do voto é anulada pela Justiça Eleitoral e, algum tempo depois, é convocado a se manifestar novamente sobre quem deve exercer o cargo de prefeito? Comparece às urnas, atendendo a obrigatoriedade, ou perde o interesse pela nova disputa? Se ele comparece, invalida mais intensamente o sufrágio?

Estas são algumas das perguntas que o artigo busca responder $^{1}$. Ele tem como objeto o comportamento do eleitor nas 113 eleições suplementares ao pleito de 2012, realizadas entre 2013 e 2015 (BRASIL. TSE, 2016a, 2016b, 2016c). Este estudo se efetiva por meio da comparação das decisões de abster-se ou de votar em branco ou nulo em relação às manifestadas na eleição ordinária.

O artigo se organiza em cinco seções. A primeira define a eleição suplementar e resenha o modo como tem sido estudada. A segunda apresenta os procedimentos metodológicos adotados pelo artigo. A terceira aborda a abstenção e discute as razões para o aumento identificado. A quarta enfoca o voto inválido e busca explicação nas investigações sobre eleições com $2^{\circ}$ turno. A quinta e derradeira seção identifica as diferenças entre os dois tipos que compõem o voto inválido e analisa o efeito do erro, do protesto e da apatia como possíveis motivações.

\section{Definições}

A expressão eleição suplementar indica a realização de nova disputa com votação popular para escolher o titular do poder executivo. Ela é determinada pela Justiça Eleitoral como consequência da anulação do pleito ordinário. O fundamento reside no art. 224 do Código Eleitoral, o qual fixa:

1 Uma versão anterior do artigo foi apresentada e publicada nos anais do II Congreso Latinoamericano de Teoría Social, realizado em Buenos Aires, em 2017. 
Comportamento eleitoral nas eleições suplementares para prefeito no Brasil (2013-2015) Alvaro Augusto de Borba Barreto • Bruno Souza Garcia

Se a nulidade atingir a mais de metade dos votos do país nas eleições presidenciais, do Estado nas eleições federais e estaduais ou do município nas eleições municipais, julgar-se-ão prejudicadas as demais votações e o Tribunal marcará dia para nova eleição dentro do prazo de 20 (vinte) a 40 (quarenta) dias. (BRASIL, 1965).

Apesar de a regra ter cinco décadas, ela passou a ter aplicação mais frequente após recentes determinações legais disciplinarem com mais precisão e rigor os crimes eleitorais e as inelegibilidades, o que tornou possível cassar com rapidez candidaturas, diplomas e mandatos ${ }^{2}$.

Anulado o pleito, é necessário reabrir o processo eleitoral. Por conseguinte, a eleição suplementar compreende a repetição não só da votação, como também de todos os passos que compõem um pleito: alistamento dos eleitores, registro de candidaturas; propaganda, votação, apuração; diplomação e posse dos eleitos. A diferença em relação ao processo ordinário é que os prazos são mais curtos, sendo definidos pelo Tribunal Superior Eleitoral (TSE) ou pelo respectivo Tribunal Regional Eleitoral (TRE).

É importante destacar que a anulação do pleito abarca os mandatos obtidos a partir dele. Consequentemente, chefes do executivo já diplomados ou em exercício de mandato perdem o cargo e precisam ser substituídos. Nesses casos, a decisão afeta o cotidiano da administração, pois faz com que políticas públicas e modelos de gestão sejam interrompidos ou nem comecem a ser implantados, assim como, durante algum tempo, o governo seja comandado por um interino (normalmente, o Presidente do respectivo legislativo).

\footnotetext{
2 No período em análise, se o atingido não obtivesse $50 \%$ dos votos, a eleição não era anulada, tampouco havia eleição suplementar, pois o $2^{\circ}$ colocado passava a ser considerado o eleito. Porém, se a anulação ocorresse na metade final do mandato, não necessariamente haveria eleição suplementar, pois a definição do novo prefeito poderia se dar por eleição indireta, aquela na qual votam apenas os membros do órgão legislativo (os vereadores, no caso). A opção pela eleição indireta dependia da existência de previsão na respectiva Lei Orgânica Municipal e/ou de decisão da Justiça Eleitoral. Essas duas modalidades não serão analisadas. Ressalva-se que o cenário sofreu modificação após o período analisado no artigo: houve a introdução dos parágrafos $3^{\circ}$ e $4^{\circ}$ ao art. 224 do Código Eleitoral, por meio da Lei 13.165/2015, os quais determinam que, se houver a cassação do vencedor do pleito, independentemente da votação obtida, será realizada eleição suplementar, com limite de seis meses antes do término do mandato. Se a vacância se der a menos de seis meses, o novo prefeito é definido em eleição indireta.
} 
Comportamento eleitoral nas eleições suplementares para prefeito no Brasil (2013-2015) Alvaro Augusto de Borba Barreto • Bruno Souza Garcia

As investigações sobre as eleições suplementares têm seguido dois caminhos principais. O primeiro realiza abordagem mais normativa, como em Salgado (2010) e Espíndola (2013), que pode ser sintetizada na pergunta: seguindo o princípio da soberania popular, o que legitima que a decisão de magistrados, de caráter não eletivo, possa prevalecer sobre a vontade da cidadania e determinar que nova votação seja realizada? E, como questão derivada, vinculada à problemática da judicialização das regras eleitorais: qual o limite desejável para a intervenção do organismo responsável pela eleição, ao formular, interpretar e aplicar regras que a disciplinam? Servem como exemplos: Ferraz Júnior (2008) e Lima (2011).

O segundo compreende os estudos voltados aos aspectos jurídico-políticos: previsões legais e construções jurisprudenciais em torno da anulação do pleito e da convocação de nova eleição; fatores que dão causa a decisões sobre nulidade e anulação; características dos processos de impugnação e/ou cassação de candidatura, diploma ou mandato; prazos de desincompatibilização (KUNTZ, 2011) e a participação do candidato que deu causa à anuIação (ZILIO, 2006).

Este segundo campo se insere na discussão em torno dos efeitos produzidos por um ambiente institucional que, em nome de garantir eleições limpas, serve de estímulo à manutenção da disputa para além das urnas. Os achados de Marchetti (2014) corroboram essa perspectiva: houve o crescimento dos recursos eleitorais entre 1990 e 2004, dos quais 58\% têm os atores políticos a questionar os concorrentes. A lógica é simples: se essa demanda não for apresentada, quem perde a eleição continuará derrotado; em contrapartida, acionar a Justiça Eleitoral não implica custos, nada é perdido se a denúncia não for aceita e, se ela tiver sucesso, surge a possibilidade de vencer.

Discutir as razões jurídico-políticas pelas quais um pleito é anulado e novamente realizado e as implicações dessa decisão para a estabilidade do sistema político são questões que têm mobilizado agendas de pesquisa. Todavia, o artigo centra-se em outra proble- 
Comportamento eleitoral nas eleições suplementares para prefeito no Brasil (2013-2015) Alvaro Augusto de Borba Barreto • Bruno Souza Garcia

mática: toma a eleição suplementar como fato e procura analisar os resultados que ela produz, tornando-se, portanto, menos normativo e mais empírico.

Este tipo de abordagem não tem sido muito comum. Foram localizados poucos trabalhos centrados nas disputas suplementares efetivamente realizadas, como os de Zalamena (2013), Coelho (2014), Garcia (2016) e Crespo (2017). As duas primeiras pesquisadoras as abordam em meio a discussões sobre judicialização das regras eleitorais. Zalamena (2013) investiga dez pleitos promovidos no Rio Grande do Sul em 2008, analisa-os em comparação aos anulados no que tange a comportamento do eleitor e resultado. Coelho (2014) centra-se naquela realizada em Coronel José Dias (PI), após 2008, e ainda aborda o grupo político vencedor nas novas eleições após 2004 e 2008, em municípios do Piauí. As duas seguintes analisam as disputas ocorridas no país em substituição ao pleito de 2012, comparando os resultados em termos de quantidade de competidores, partidos, coligações e grupos políticos vencedores ${ }^{3}$.

Como resultado dessa carência, a Ciência Política ainda não tem muitas respostas sobre os significados da realização de eleições suplementares. Em especial, como propõe este artigo, há poucas análises sobre o modo como o eleitor se comporta diante de tal situação e, consequentemente, os impactos que ela causa.

\section{Metodologia}

Como já foi indicado, a pesquisa compreende as 113 eleições suplementares ao pleito de 2012. Foram elencadas quatro variáveis de estudo: abstenção, voto inválido, voto nulo e voto em branco.

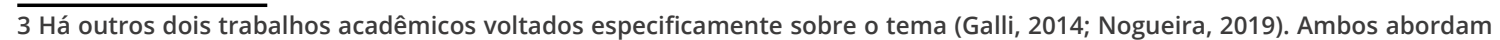
elementos constituintes das decisões judiciais que convocam eleições suplementares e as motivações que as fundamentam. 
Comportamento eleitoral nas eleições suplementares para prefeito no Brasil (2013-2015) Alvaro Augusto de Borba Barreto • Bruno Souza Garcia

Como o propósito é analisar o comportamento do eleitor na eleição suplementar em comparação à eleição ordinária, o dado primário se refere ao número absoluto registrado nas duas disputas. A seguir, foram calculados os respectivos percentuais: o da abstenção, pela divisão da quantidade de faltosos em relação ao eleitorado apto; os de voto em branco e nulo tiveram como divisor o total de votantes; e o de inválido agrega os dois índices anteriores.

No passo subsequente, foram comparados os índices das duas eleições. O parâmetro é simples: se eles registraram "aumento" ou

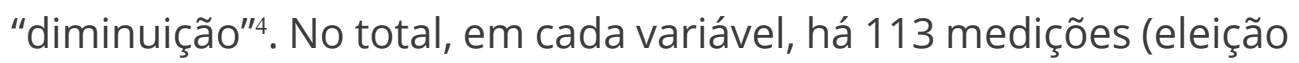
suplementar em relação à ordinária).

Para dimensionar as tendências identificadas, esses índices foram comparados com aqueles registrados em outras eleições, notadamente a partir da adoção da urna eletrônica. Igualmente, dados sociais do Índice de Desenvolvimento Humano Municipal - Educação (IDHM-Educação) foram agregados para balizar a investigação e tentar explicar as tendências identificadas. Por fim, os resultados foram analisados à luz da literatura que aborda este tipo de comportamento, em busca de parâmetros de comparação.

A fonte principal para os dados foi o site do Tribunal Superior Eleitoral (BRASIL, 2016d, 2016e, 2016f). Resultados que o TSE não mais apresentava foram alcançados no portal G1. Para identificar o nível educacional dos municípios foi utilizado o IDHM-Educação 2010, coletado no Atlas Brasil.

Explicitam-se alguns procedimentos sobre o modo como as informações sobre votos inválidos e nulos foram obtidas e consideradas pela pesquisa, pois, na base de dados do TSE, eleições anuladas aparecem com mais de $50 \%$ dos votos nulos, sem que sejam distinguidos aqueles manifestados pelo eleitor e aqueles que a Justiça Eleitoral assim considerou, embora tenham sido originalmente atribuídos a algum candidato.

Há a situação em que a cassação da candidatura ocorreu após a eleição. O resultado divulgado por ocasião da apuração trazia

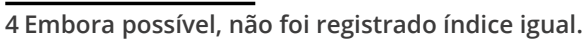


Comportamento eleitoral nas eleições suplementares para prefeito no Brasil (2013-2015) Alvaro Augusto de Borba Barreto • Bruno Souza Garcia

a votação desses concorrentes e os votos nulos atribuídos pelo eleitor, por isso, a solução foi simples: localizá-los nos sites que os divulgaram, como o portal G1.

A segunda é um pouco mais complexa, pois envolve candidatos que concorreram impugnados, com possibilidade de reversão da situação na justiça (o que não se confirmou). Na divulgação oficial, os votos deles apareciam "zerados" ou já figuravam dentre os nulos. Foi preciso localizar relatórios eleitorais, que são públicos, mas pouco propagados, para identificar o desempenho desses candidatos (BRASIL. TSE, 2016g). Essa votação foi diminuída do total de votos nulos constante no resultado oficial para alcançar os anulados pelo eleitor e, enfim, recalcular o percentual em relação aos sufrágios emitidos. Legalmente, o resultado obtido pela pesquisa nunca existiu, embora corresponda a aquele saído das urnas, pois tais candidatos jamais se tornaram elegíveis. Porém, teve de ser construído para identificar o contingente que, frente às opções existentes, preferiu anular o voto.

Ambas as situações foram registradas em dez dos pleitos suplementares, sendo adotados os mesmos procedimentos.

\section{Abstenção}

Abstenção é o "termo usado para definir a não participação no ato de votar", sendo "calculado como o percentual de eleitores que, tendo direito, não se apresentam às urnas" (BRASIL. TSE, 2016f). Ele não distingue os que obrigatoriamente devem fazê-lo (alfabetizados que possuem entre 18 a 70 anos) dos que, estando alistados, podem comparecer se quiserem, caso dos que possuem 16 e 17 anos, mais de 70 ou são analfabetos. Lembra-se que a eleição suplementar opera como se fosse uma disputa ordinária, portanto, vigoram as mesmas regras relativas ao caráter obrigatório ou facultativo do voto, conforme o tipo de eleitor. 
Comportamento eleitoral nas eleições suplementares para prefeito no Brasil (2013-2015) Alvaro Augusto de Borba Barreto • Bruno Souza Garcia

Tabela 1 - Abstenção na eleição suplementar (2013-2015) em comparação à anulada (2012)

\begin{tabular}{lll}
\hline ABSTENÇÃO & $\mathrm{N}$ & $\%$ \\
\hline Aumentou & 106 & 93,8 \\
Diminuiu & 7 & 6,2 \\
Total & 113 & 100 \\
\hline
\end{tabular}

Fonte: BRASIL (2016).

Como mostra a Tabela 1, em 93,8\% das eleições suplementares houve redução no comparecimento. A informação é contundente: a intensidade com que o fenômeno se verifica indica o aumento da abstenção na nova eleição em comparação àquela registrada no pleito ordinário e que foi anulado.

Porém, o cenário é ainda mais nuançado. Dos sete municípios $(6,2 \%)$ em que a abstenção diminuiu, em quatro houve cadastramento biométrico obrigatório no intervalo entre as duas eleições. Além de cancelar o título dos que não atenderam à convocação para realizar novo alistamento, o cadastramento tem a tendência a reduzir o eleitorado, pois identifica de modo exclusivo cada eleitor e elimina eventuais duplicidades, atualiza a base de dados ao retirar os falecidos e ao regularizar a situação dos que não mais residem no município em que estão alistados (Brasil, TSE, 21 jan. 2016). Também tende a reduzir a abstenção ou, melhor, a identificar a ausência ocorrida entre eleitores que, de fato, poderiam votar. Logo, a menor ausência não se deve a uma mudança comportamental do eleitor, e sim à modificação em um dos referenciais de medição (eleitorado), que se tornou mais preciso em relação ao existente na eleição ordinária.

Considerando a análise acima, pode-se supor que as taxas de abstenção dos municípios em que não houve cadastramento biométrico obrigatório estão artificialmente elevadas. Apesar disso, como as bases eleitorais a partir das quais elas foram calculadas não sofreram modificação substancial, ambas incorporam contingentes semelhantes de distorção proveniente da desatualização dos registros, o que valida a comparação. 
Comportamento eleitoral nas eleições suplementares para prefeito no Brasil (2013-2015) Alvaro Augusto de Borba Barreto • Bruno Souza Garcia

O desafio é explicar a razão para esse crescimento tão contundente da abstenção, que ultrapassa $90 \%$ dos pleitos suplementares analisados. Uma grande variedade de estudos tem procurando identificar os fatores que contribuem para que ela ocorra - ou, em sua outra face, a redução do comparecimento ${ }^{5}$. Franklin (1996) cita três teorias, não necessariamente excludentes entre si: dos recursos, da mobilização, da motivação instrumental. Na avaliação de Lima Júnior e Anastasia (1999), a teoria dos recursos reputa a abstenção a características que os ausentes apresentam individualmente e/ou que incidem diretamente sobre cada um deles. A teoria da mobilização enfatiza elementos contextuais de cada eleição em particular. Por fim, a terceira interpreta a abstenção a partir da teoria da escolha racional.

A teoria dos recursos é a de maior difusão. De inspiração sociológica, destaca que uma ou mais características individuais de ordem demográfica e socioeconômica (idade, escolaridade, renda etc.) ou estrutural (PIB, IDH, urbanização, distribuição dos locais de votação etc.) explicam a ausência (POWER, ROBERTS, 1995; LIMA JÚNIOR, 1990; MATTOS NETO, 1997; VITULLO, 2002; COSTA, 2007; FRANKLIN, LYONS, MARSH, 2004; WATTENBERG, 2006; BLAIS, GIDENGIL, NEVITTE, 2004). Conforme Freire (2003, p. 151), o pressuposto - não necessariamente verificado empiricamente - é:

Quanto maior o nível de recursos, maior tenderá a ser a propensão para os indivíduos participarem na política, seja porque esses mesmos recursos tornam mais fácil/menos custosa a obtenção e processamento de informação política (Downs, 1957), seja porque os indivíduos com maiores recursos gozam de maior estatuto e maior integração social e política, logo são mais propensos a participar na política.

Um conjunto significativo de pesquisas procurou determinar qual ou quais recursos são mais decisivos para a ocorrência do fenômeno. Para Elkins (2000), Blais, Gidengil, Nevitte (2004) e Gallego

5 Para resenha de estudos internacionais: Geys (2006); Ribeiro; Borba; Silva (2015). Para investigações nacionais: Costa (2007); Silva (2016). 
Comportamento eleitoral nas eleições suplementares para prefeito no Brasil (2013-2015) Alvaro Augusto de Borba Barreto • Bruno Souza Garcia

(2009) é a escolaridade. Freire e Magalhães (2002), Franklin, Lyons, Marsh (2004), Wattenberg (2006) e Gallego (2009) destacam a faixa etária.

Franklin (1996) argumenta que essas interpretações não conseguem efetivamente explicar as razões da abstenção. Ele sustenta tal perspectiva ao verificar que a variação na taxa de comparecimento, relativa ao período 1960-1990, é mais intensa na comparação entre países do que quando a análise é promovida entre os grupos de características individuais desses países, logo: "importa se alguém é rico ou pobre, educado ou sem instrução, interessado em política ou não, mas nenhuma delas é tão relevante quanto se o indivíduo é um australiano ou um americano".

A teoria da mobilização política destaca que o comparecimento é produto da capacidade que demonstram os atores envolvidos na disputa (diretamente, como candidatos e partidos; ou indiretamente, como grupos de interesse e mídia) para mobilizar o eleitor para ir às urnas 6 . Vitullo (2002, p. 229) enfatiza que, desse modo, a participação eleitoral vai variar conforme as circunstâncias específicas de cada disputa, sendo, por conseguinte, conjuntural. Como decorrência dessa interpretação, na qual não ir votar é o comportamento esperado ou, ao menos, o comparecimento precisa ser estimulado por fatores externos, a "abstenção ocasional" passa a ser a regra. Vitullo a denomina como "voto intermitente", ou seja, o comparecimento pode ou não se verificar segundo a importância que o eleitor dá às questões em voga a cada pleito em particular, o que não seria indicador de apatia ou de desinteresse, e sim de alto grau de politização e de mobilização política.

Essa interpretação, que vê o não comparecimento de modo positivo, é contestada por autores que concebem o crescimento da abstenção, verificado a partir dos anos 1990, nos países desenvolvidos, como um indicador da perda de capacidade de mobilização das instituições políticas tradicionais. Logo, a redução da participação eleitoral refletiria uma crise muito mais profunda

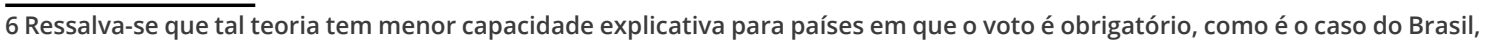
haja vista que ela é formulada para cenários institucionais em que o sufrágio é facultativo. 
Comportamento eleitoral nas eleições suplementares para prefeito no Brasil (2013-2015) Alvaro Augusto de Borba Barreto • Bruno Souza Garcia

(FREIRE, MAGALHÃES, 2002; JUSTEL, 1997; PEREA, 1999). Ela implica o desencanto com a política em geral, e não com um determinado tipo de pleito ou com as opções apresentadas em uma disputa específica. Logo, seria um abstencionismo mais permanente e que colocaria em xeque a própria fundamentação da democracia7.

Franklin (1996, p. 222) considera que a teoria da motivação instrumental consegue explicar com mais eficiência a participação eleitoral. De um lado, porque não negligencia as variáveis mobilizadas pelas duas teorias anteriores. De outro, porque agrega elementos para os quais elas não atentaram. Para ele, o pressuposto básico para que o eleitor compareça às urnas reside na intenção de afetar o curso das políticas públicas. Em outros termos, o autor argumenta nos termos daquilo que Santos (1987) chama de "retorno esperado do voto" ou Figueiredo (1990) denomina como "efetividade do voto".

Em decorrência desse pressuposto, não cabe afirmar que o comparecimento seja produto de um estado mental do indivíduo ou de uma determinada circunstância cultural da sociedade. Votar tem de ser concebido como resultado da ação desenvolvida pelo indivíduo quando ele tem interesse e sente-se capacitado a produzir o resultado ambicionado. É nessa perspectiva que Gallego (2009, p. 26) incorpora características da teoria dos recursos à da motivação instrumental e pondera que a não participação de determinados grupos sociais - como os menos escolarizados e os mais jovens - está associada ao fato de eles entenderem que não possuem capacidade para alterar o funcionamento do sistema político e que, por isso, não vale a pena assumir o custo de votar.

A ênfase de Franklin (1996) está em apontar fatores institucionais que fazem com que os custos e/ou os benefícios do comparecimento cresçam e/ou sejam amortizados, servindo como estímulo/desincentivo ao voto. Dentre eles, estão se o comparecimento é facultativo ou obrigatório; se a fórmula eleitoral é pro-

\footnotetext{
7 Como pondera Miguel (2002), há um conjunto de autores - como Schumpeter, Lipset, Huntington -, que não pensa dessa forma, pois vê a ausência do eleitor como um indicador de satisfação com o sistema político, satisfação tão intensa que não há interesse e/ou necessidade de manifestar opinião nas urnas. Ele denomina tal visão como uma tendência a "domesticar a democracia".
} 
Comportamento eleitoral nas eleições suplementares para prefeito no Brasil (2013-2015) Alvaro Augusto de Borba Barreto • Bruno Souza Garcia

porcional, majoritária ou mista; se o voto é presencial ou pode ser emitido à distância (como exemplo, pelo correio); se o horário de funcionamento das urnas é amplo ou restrito; se o período de votação compreende um ou mais dias e se ele ocorre em dia útil e/ ou domingos; se o tipo de cargos em disputa é do Executivo, do Legislativo ou ambos; se esses postos são municipais, estaduais, nacionais ou uma combinação entre eles. Na visão do autor, voto voluntário e sistema proporcional, que tem possibilidade de maior aproveitamento do sufrágio, são fatores que proporcionam a motivação instrumental e aumentam a probabilidade do comparecimento. Outros estudos, como os de Figueiredo (1990), Lima Júnior e Anastasia (1999) e Freire e Magalhães (2002), enfatizam a maior capacidade de atrair eleitores que a escolha para cargos do poder Executivo tem sobre eleições exclusivamente para o Legislativo.

Em seu estudo, Franklin (2002, p. 164) testou como essas variáveis de cunho institucional afetaram as taxas de abstenção durante cinco décadas (1940-1990), em 31 países. Como resultado, ele concluiu que "um país com poucas eleições relevantes e um sistema partidário que não era muito competitivo pode facilmente mostrar níveis de participação $45 \%$ abaixo de um país com eleições de alta relevância e um sistema de partidos altamente competitivo". Desse modo, há compatibilidade entre esses resultados e a declaração de Florentino (2007, p. 5), segundo a qual:

Antes de responsabilizar os eleitores faltosos pelas taxas de abstenção eleitoral, muitas vezes o adequado seria estudar como aquele sistema político se organiza, pois assim se poderia dizer quais estímulos existem à participação, e então se averiguar como esses estímulos são desigualmente distribuídos na sociedade, visto que alguns grupos parecerem participar mais que outros.

Argumenta-se que essas pesquisas estão partindo de alguns pressupostos equivocados, o que compromete o modo como concebem a abstenção. O primeiro deles é supor que a tendência "natural" do eleitor é não comparecer às urnas, caso a decisão depen- 
Comportamento eleitoral nas eleições suplementares para prefeito no Brasil (2013-2015) Alvaro Augusto de Borba Barreto • Bruno Souza Garcia

desse unicamente de sua escolha e de sua vontade. Um cálculo racional demonstra que, dado o peso de um voto e a capacidade de ele definir a disputa, o custo será sempre mais elevado do que o benefício. Logo, o comportamento esperado seria não comparecer.

O segundo é que, de um lado, tal eleitor é um ator interessado, politizado e que, após cogitar as alternativas, decide se vai ou não às urnas. De outro, a politização não implica interesse pela política ou uma postura crítica frente às alternativas que lhe são oferecidas, tanto que o comportamento "normal" é abster-se. Não há a preocupação em verificar quem é o eleitor mais "mobilizável" a partir da decisão tomada em eleições anteriores, de suas vinculações políticas ou sociais, tendência política etc. Na mesma medida, o eleitorado pode ser mobilizado de diferentes formas, e a maioria delas não vai apelar para o cálculo racional.

A leitura das pesquisas produzidas a partir dessas teorias explicativas mostra o quanto elas produzem evidências que corroboram seus pressupostos. Logo, há muitas investigações que demonstram o peso de diferentes recursos individuais a contribuírem para o não comparecimento. Outras tantas o fazem com variáveis institucionais a estimularem ou constrangerem o eleitor a votar. Igualmente, dados indicam que as instituições políticas tradicionais, em especial os partidos, sofrem de um déficit de capacidade de mobilização e que o eleitorado está mais resistente aos estímulos e mais volátil em suas opiniões políticas.

Entretanto, quando analisadas em conjunto, e não isoladamente, o que essas pesquisas mostram é que cada teoria traz uma perspectiva analítica própria, a partir da qual seleciona indicadores a serem testados e, como resultado, identifica diferentes elementos que contribuem e/ou determinam a abstenção. Nesse sentido, cada pesquisa e sua respectiva teoria constroem a sua própria "abstenção", considerando-a como sinônimo do fenômeno. Consequentemente, seus resultados são a explicação que o contempla integralmente.

Porém, o que elas produzem é um mosaico de diferentes olhares sobre esse fenômeno, que é em si mesmo diversificado. De tal 
Comportamento eleitoral nas eleições suplementares para prefeito no Brasil (2013-2015) Alvaro Augusto de Borba Barreto • Bruno Souza Garcia

modo que, de fato, há diferentes não comparecimentos, motivados por diferentes razões.

Se a perspectiva for a que está presente no parágrafo acima, pode-se apelar para uma visão que busque integrar as diferentes teorias, conjugando esforços explicativos, pois o fenômeno não é unívoco. Ou seja, determinadas abstenções podem ser produzidas por determinadas motivações, como as de ordem pessoal, social etc., e, na mesma medida, outros não comparecimentos, por outras motivações.

Ainda assim, pondera-se que a maioria dessas vertentes explicativas e suas respectivas variáveis não pode ser aplicada ao objeto deste estudo. Elas se prestam à comparação entre unidades distintas e/ou a investigações longitudinais, enquanto o artigo compara duas eleições do mesmo município, realizadas em curto intervalo de tempo (no máximo, três anos e dois meses). Assim, não há oportunidade para que se produzam mudanças significativas na composição do eleitorado e nos indicadores socioeconômicos, tampouco de ordem estrutural e nas regras que disciplinaram os pleitos ${ }^{8}$.

A explicação para o crescimento da abstenção na eleição suplementar tem que ser buscada em características conjunturais relativa à própria realização da nova eleição, no modo como o eleitorado a percebe e na capacidade que os agentes têm de motivar o eleitor para votar. De um lado, a frequência do chamamento às urnas (NORRIS, 2003), menos tempo de campanha para mobilizar o eleitorado 9 e de informação quanto à obrigatoriedade do voto são fatores que podem ter contribuído para este cenário. De outro, características subjetivas podem ter levado o eleitor a expressar contestação (protesto) ou apatia (indiferença) por meio de sua ausência.

$\mathrm{Na}$ falta de entrevistas com esses eleitores capazes de evitar a falácia ecológica de extrair explicações para comportamentos indi-

\footnotetext{
8 A única modificação é o recadastramento biométrico. Mas ele abarcou um pequeno número de municípios (oito), em cuja maioria houve redução na abstenção.

9 Como já foi informado, os prazos da eleição suplementar são mais curtos do que os da disputa ordinária.
} 
Comportamento eleitoral nas eleições suplementares para prefeito no Brasil (2013-2015) Alvaro Augusto de Borba Barreto • Bruno Souza Garcia

viduais a partir de dados agregados ${ }^{10}$, podem-se encontrar evidências sobre a validade dessa explicação por outro procedimento, como observar o índice de abstenção nas eleições ordinárias de 2016 nesses municípios. Afinal, se fatores outros que não os atitudinais provocaram o aumento da abstenção nos pleitos suplementares de 2013-2015, e como eles não sofreram modificação, deveriam continuar a produzir efeitos. Consequentemente, o índice de abstenção em 2016 deveria ser maior do que de 2012 e o registrado na eleição suplementar.

Tabela 2 - Comparação da abstenção nos municípios em que houve eleição suplementar no período 2012-2016, em percentual

\begin{tabular}{lrrr}
\hline ABSTENÇÃO & SUPLEM. $\rightarrow$ 2012 & 2016 $\rightarrow$ SUPLEM. & 2016 $\rightarrow 2012$ \\
\hline Aumentou & 93,8 & 13,3 & 62,8 \\
Diminuiu & 6,2 & 86,7 & 37,2 \\
\hline TOTAL & $(113)$ & $(113)$ & $(112)$ \\
\hline
\end{tabular}

Fonte: BRASIL. TSE (2016, 2016d)

Conforme a Tabela 2, em 93,8\% dos casos, a abstenção cresceu na eleição suplementar em relação ao pleito de 2012. Porém, ao comparar o índice da suplementar com o do pleito municipal de 2016 , verifica-se redução em $86,7 \%$ das medições. Na comparação entre as duas disputas ordinárias, a abstenção cresceu em $62,8 \%$ das observações.

Esses dados indicam duas situações. A primeira é a tendência de crescimento da abstenção entre os dois pleitos ordinários, verificada em aproximadamente dois terços dos municípios analisados. A segunda é que a eleição suplementar, realizada no intervalo entre essas duas disputas, registra ampliação do índice em quase $100 \%$ dos casos em relação ao ordinário que a antecedeu e redução face ao que a sucede. Enfim, há um "pico" de abstenção nos pleitos suplementares.

10 Exceção está em pesquisa realizada em Criciúma, em 2013, que identificou que somente 37\% dos eleitores estavam interessados na disputa suplementar do município (EBC, 2 mar. 2013). 
Comportamento eleitoral nas eleições suplementares para prefeito no Brasil (2013-2015)

Gráfico 1 - Variação da abstenção nos municípios em que houve eleição suplementar no período 2012-2016

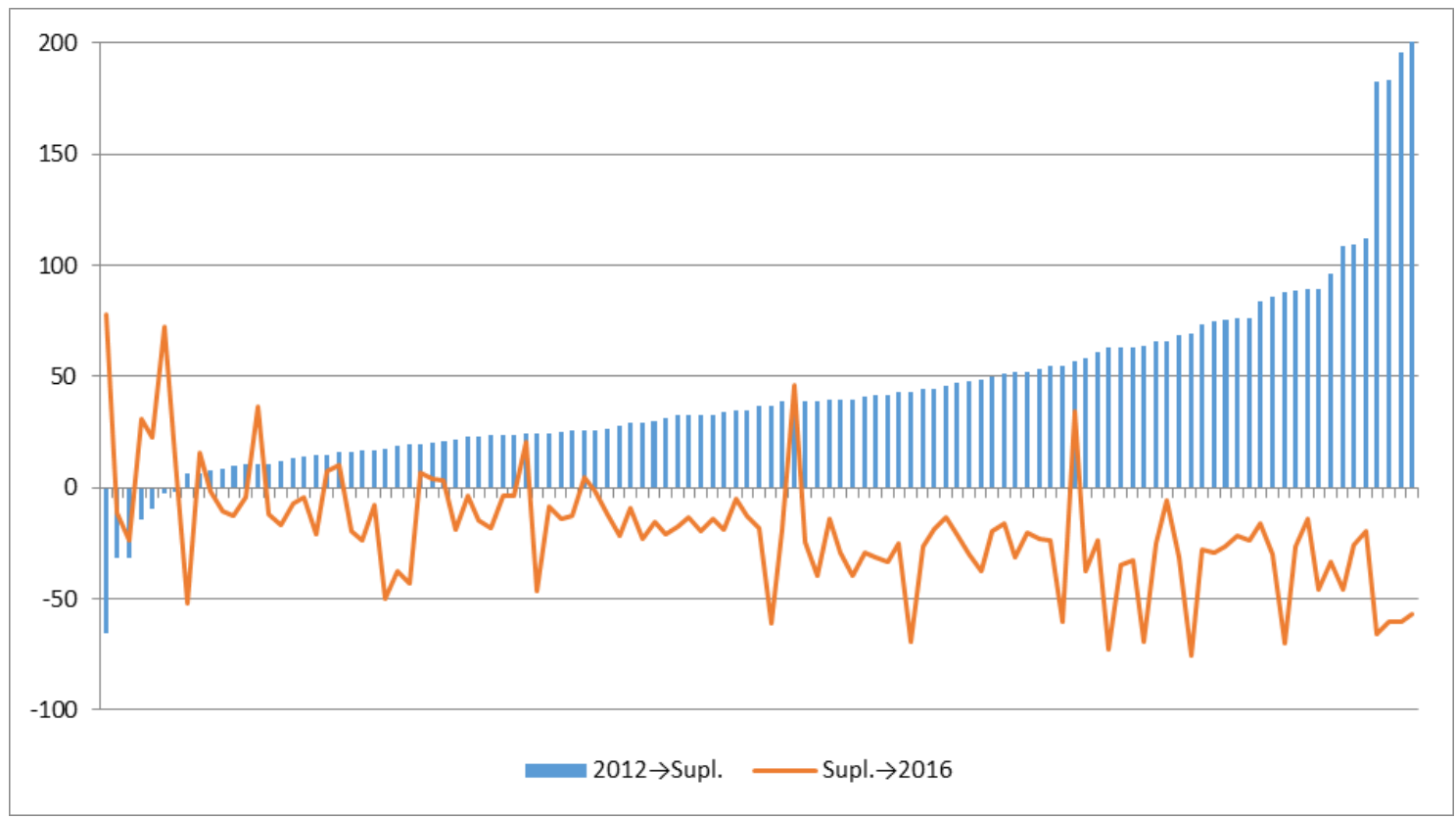

Fonte: BRASIL. TSE $(2016,2016 d) r=-0,56$

O Gráfico 1 apresenta as informações calculadas pela taxa de variação no índice de abstenção registrada na passagem da eleição de 2012 para a suplementar e desta para a de 2016. O contraste é nítido e aponta a tendência de alta na $1^{\text {a }}$ medição e de queda na $2^{\mathrm{a}}$.

Esse conjunto de informações indica que algum fator fez com que, em geral, o índice de abstenção desse um salto na eleição suplementar em relação a 2012, depois caísse em 2016, embora sem retornar ao patamar anterior. Argumenta-se que o modo como o eleitorado a vislumbrou fez com que uma parcela significativa se abstivesse e, na comparação com os pleitos ordinários, ela se tornasse um "ponto fora da curva".

Pode-se especular que tenha havido desconfiança em relação ao processo eleitoral suplementar, descrença na efetividade do voto após a anulação do pleito ordinário, insatisfação com o ambiente político local e/ou com as opções de candidatura. Ao que se pode acrescentar que, normalmente, a anulação ocorre após longo processo de idas e vindas no âmbito da Justiça Eleitoral, o 
Comportamento eleitoral nas eleições suplementares para prefeito no Brasil (2013-2015) Alvaro Augusto de Borba Barreto • Bruno Souza Garcia

que impacta o cotidiano do município; que há provavelmente a impossibilidade de o preferido pelo eleitorado participar da nova disputa (por ser quem deu causa à anulação), sem contar que o escolhido terá período mais curto para exercer o mandato.

As bases atitudinais seriam racionais e semelhantes àquelas identificadas no estudo de Silva (2016, p. 173), realizado a partir do Estudo Eleitoral Brasileiro (ESEB) 2010: “o eleitor que se abstém, o faz por não perceber a eficácia no seu voto e por ser indiferente quanto a quem governa o país. Ou seja, se abster é melhor do que se deslocar até às urnas para votar, sem que tal ação produza resultados que impacte na vida do eleitor".

\section{Voto inválido}

É todo aquele que não produz efeito prático na disputa. O voto inválido compreende a soma dos votos que não são atribuídos a candidato ou a partido (voto de legenda). Distingue-se da abstenção, pois apenas os eleitores que comparecem à votação podem invalidar o sufrágio. Não por acaso, ele e os tipos que o compõem (branco e nulo) são denominados "voto". O modo como o voto inválido é calculado também expressa essa diferença, pois tem os votantes como divisor, enquanto a abstenção é tradicionalmente calculada no Brasil a partir do eleitorado apto.

Tabela 3 - Voto inválido na eleição suplementar (2013-2015) em comparação à anulada (2012)

\begin{tabular}{lrr}
\hline INVÁLIDO & N & $\%$ \\
\hline Aumentou & 31 & 27,4 \\
Diminuiu & 82 & 72,6 \\
TOTAL & 113 & 100 \\
\hline
\end{tabular}

Fonte: BRASIL. TSE (2016, 2016g); G1 (2016) 
Comportamento eleitoral nas eleições suplementares para prefeito no Brasil (2013-2015) Alvaro Augusto de Borba Barreto • Bruno Souza Garcia

Como indica a Tabela 3, o contingente de votos invalidados diminuiu em $72,6 \%$ das eleições suplementares em comparação ao índice registrado nos pleitos ordinários.

Não há muito estudos nacionais voltados especificamente ao voto inválido, pois são mais comuns os que o analisam em conjunto com a abstenção. Os existentes apresentam as mesmas vertentes explicativas adotadas para o não comparecimento. Alguns exemplos: Lima Júnior (1990) o associa à baixa escolaridade, o que não foi confirmado na investigação de Borba (2008), cujos resultados, calcados no ESEB 2002, apontam para a insatisfação com o funcionamento das instituições políticas. O estudo de Silva et al. (2014), que se serviu de dados da pesquisa Latin American Public Opinion Project (LAPOP) 2010, verificou a contribuição relevante para a menor probabilidade da ocorrência desse tipo de voto da elevação da faixa etária, da confiança nas instituições e no processo eleitoral, bem como da avaliação sobre a economia.

Novamente, as principais teorias não contemplam a especificidade das eleições suplementares, pois as mudanças nos indicadores que permitiriam adotá-las como modelo explicativo não existem ou o tempo decorrido não permite que sejam significativas. Como ponderado, a alternativa passa a residir nos aspectos atitudinais.

Porém, o comportamento do eleitorado foi distinto: a abstenção aumentou em 93,8\% dos casos e a invalidação diminuiu em $72,6 \%$. Assim, os elementos que podem explicar um não são os mesmos que cabem ao outro, o que consagra a interpretação de Lima Júnior (1993, p. 101) de que "o que leva o eleitor a abster-se não é exatamente o que leva o eleitor a votar em branco ou a anular o voto" e desmente a de Lavareda (1991, p. 40), segundo a qual eles seriam os equivalentes funcionais da abstenção em países de voto obrigatório.

Esse comportamento identificado nas eleições suplementares não é inédito, pois se aproxima do apresentado nas eleições brasileiras em que há dois turnos. Ao analisar 323 pleitos, realizados 
Comportamento eleitoral nas eleições suplementares para prefeito no Brasil (2013-2015) Alvaro Augusto de Borba Barreto • Bruno Souza Garcia

entre 1989 e 2016, a pesquisa identificou aumento da abstenção na passagem do $1^{\circ}$ para o $2^{\circ}$ turno em $97,5 \%$ e redução do voto inválido em $87,9 \%{ }^{11}$. Diante de tendências semelhantes, é possível estender à eleição suplementar as explicações dadas à situação registrada nesses pleitos.

Ao estudar a disputa presidencial de 1989, Reis (1991) identificou uma correlação ( $r$ de Pearson) de 0,98 nas taxas de abstenção do $1^{\circ}$ e do $2^{\circ}$ turno e de 0,67 nos índices de votos em branco e nulo. Silva $(2016$, p. $85 ; 133)$ destacou que esses dados indicam o caráter "mais estrutural" da primeira e a dimensão conjuntural do segundo.

Ao comentar as eleições presidenciais de 1989 a 2014, Silva (2016, p. 148) reafirmou essas explicações: a variação atende às peculiaridades do $2^{\circ}$ turno em relação ao $1^{\circ}$, caso de redução das ofertas do mercado eleitoral a duas possibilidades e do aumento do custo do retorno às urnas em um curto espaço de tempo, logo crescem as chances de o eleitor abster-se e, se compareceu, de optar por uma das ofertas disponíveis. Na mesma linha, Gulisano e Darwich (2016, p. 10) ponderam que o eleitor cujo candidato favorito não foi para o $2^{\circ}$ turno poderia ficar menos motivado $a$ ir às urnas, o que explicaria o aumento da abstenção. Porém, quem decide votar supõe que sua escolha tenha mais peso decisório, uma vez que há menos competidores e que pode optar pelo "menos ruim".

\section{Voto em branco e voto nulo}

Há outra corrente explicativa sobre o tema, mas que não foi abordada até o momento. É a que reputa a invalidade a erro, a um equívoco do eleitor que, de fato, não pretendia esterilizar sua escolha. Essa possibilidade figura em estudos nacionais, como os

$\overline{11 \text { São cinco eleições }}$ presidenciais (1989-2014); 77 para governador (1994-2014); 241 para prefeito (1996-2016), com índices semelhantes: aumento da abstenção em $100 \%$ nas presidenciais; $98,7 \%$ nas estaduais; $97,1 \%$ nas municipais; redução dos inválidos em 100\%, 85,7\% e 88,4\%, respectivamente (BRASIL. TSE, 2016e). 
Comportamento eleitoral nas eleições suplementares para prefeito no Brasil (2013-2015) Alvaro Augusto de Borba Barreto • Bruno Souza Garcia

de Soares (2001, p. 317-318), Fleischer (2002, p. 82) e Lamounier (1980, p. 72-73, grifo do autor). Este último autor comenta:

\begin{abstract}
A proporção de votos em branco e nulos é, pois inequivocamente maior nas áreas mais pobres. Esta constatação lança graves dúvidas sobre a interpretação habitual, que os vê quase exclusivamente como votos de protesto, e sugere que fatores de outra ordem, tais como a desinformação ou a própria dificuldade em votar, acham-se presentes.
\end{abstract}

Nicolau (2002, 2004, 2015) é quem analisa sistematicamente como o erro acontece e quais fatores o causam. Ele não desconsidera que uma parcela do eleitorado o faça por protesto (NICOLAU, 2002, p. 293), mas o vincula majoritariamente às exigências estabelecidas para votar e à capacidade cognitiva do eleitorado para cumpri-las.

Demonstra o argumento ao analisar a eleição de 1998, em que parte do eleitorado votou em papel e outra na urna eletrônica, ocasião em que se reduziu o contingente de votos invalidados ${ }^{12}$. A urna eletrônica produziu tal efeito ao simplificar o procedimento de votação e ao reduzir os obstáculos para que os eleitores pudessem expressar de modo válido suas escolhas: substituiu a exigência de assinalar " $x$ ", escrever nomes e/ou números pela digitação de algarismos, realizada a partir de um display semelhante ao do telefone, o que é simples e habitual ao conjunto do eleitorado, especialmente o menos escolarizado, mais afetado pelas exigências do voto em papel.

Podem ser acrescentadas outras duas facilidades da urna eletrônica que não são oferecidas pela cédula física: (1) a tela informa, via texto e fotografia, a qual candidato corresponde o número teclado e/ou se foi digitado número inexistente; (2) o eleitor é obrigado a apertar a tecla "confirma" para que o voto se efetive

12 Estudos internacionais também abordam como diferentes procedimentos de votação ou da estrutura da cédula afetam a validação. Como exemplo: Calvo, Escolar, Pomares (2009); Kimball, Kroft (2008); Dee (2007); Hill, Young (2007); Power, Garand (2007); Reynolds, Steenbergen (2006); Ansolabehere, Stewart (2005); Power, Roberts (1995); McAllister, Makkai (1993). 
Comportamento eleitoral nas eleições suplementares para prefeito no Brasil (2013-2015) Alvaro Augusto de Borba Barreto • Bruno Souza Garcia

(HIDALGO, 2010, p. 13; MORAES, 2012, p. 16-18; FUJIWARA, 2015, p. 428-429).

Nicolau (2002, p. 287) mostra que mudanças no procedimento de votação e/ou na estrutura do boletim de voto afetam o contingente de votos invalidados. Seguindo essas constatações, Power e Roberts (1995) demonstram que nos anos 1940-1950, quando as cédulas eram fornecidas pelos próprios partidos, o índice era pequeno, assim como, que as invalidações cresceram significativamente na década de 1960, após o Brasil adotar a cédula única (modelo australiano), que exigia o preenchimento do eleitor.

A teoria do erro pode ajudar a entender uma questão relativamente pouco explorada: o sufrágio inválido é produto da soma de dois comportamentos distintos (voto em branco e nulo), o que abre a possibilidade de que o resultado seja determinado pelo crescimento e/ou pela redução de um deles.

Considerando a eventual imprecisão decorrente dessa circunstância, a seguir, os dados sobre as eleições suplementares em análise são desagregados.

Tabela 4 - Variação percentual de voto em branco e nulo na eleição suplementar (2013-2015) em comparação à anulada (2012)

\begin{tabular}{lrr}
\hline RESULTADO & EM BRANCO & NULO \\
\hline Aumentou & 41,6 & 18,6 \\
Diminuiu & 58,4 & 81,4 \\
TOTAL & $(113)$ & $(113)$ \\
\hline
\end{tabular}

Fonte: BRASIL. TSE (2016, 2016g); G1 (2016)

A Tabela 4 revela diferenças no comportamento do eleitor. Embora em ambos tenha havido redução na maioria dos pleitos, no voto nulo ela foi bem mais intensa do que no em branco: $81,4 \%$ e $58,4 \%$, respectivamente. 
Comportamento eleitoral nas eleições suplementares para prefeito no Brasil (2013-2015) Alvaro Augusto de Borba Barreto • Bruno Souza Garcia

Se há poucas investigações que tratam especificamente dos votos inválidos, são ainda mais restritas as que abordam separadamente seus formadores. Conforme Driscoll e Nelson (2014, p. 547), apesar de reconhecidos como modalidades distintas de voto, a literatura internacional os considera como equivalentes.

Uma das exceções é justamente a investigação desses autores. Por meio de resultados eleitorais e de um survey (LAPOP, 2012), eles analisaram a primeira eleição direta para juízes de quatro tribunais superiores da Bolívia, ocorrida em 2011. As taxas desses dois tipos de voto inválido foram elevadas, mas puderam ser distinguidos em suas motivações: o em branco decorreu de falta de entendimento sobre a decisão que estava em jogo, sendo emitido por eleitores com baixo nível educacional; e o nulo foi um protesto contra a medida, convocado pela oposição ao governo.

Pode-se começar a análise pela distinção conceitual. O voto em branco se configura pelo retorno da cédula como ela foi recebida pelo eleitor, ou seja, sem preenchimento. Ou, se existir tal possibilidade, com registro pela opção "branco". Conforme Porto (1995), ele difere da abstenção e do voto nulo por ser uma explícita recusa das opções oferecidas. Igualmente, seja porque o sufrágio é obrigatório (como no Brasil), seja por disposição própria, o eleitor não rejeita o sistema representativo, pois se dirige ao local de votação e exerce o voto. Logo, supõe-se que, com alternativas diferentes, ele poderia optar por uma delas, o que faz dessa escolha uma circunstância, não necessariamente uma convicção.

Um dos poucos estudos que procura evidências sobre o significado do voto em branco é o de Silva (2013). Os resultados reforçam a dificuldade de interpretação, pois ele não conseguiu relacioná-lo de modo relevante a nenhuma das variáveis elencadas e que incluíam características socioeconômicas dos municípios (PIB, IDH, renda per capita, taxa de analfabetismo).

Já o nulo implica manifestação no boletim de voto que torna impossível validar a decisão. Essa definição contempla quem adota um procedimento de votação que materializa a inutilização da cédula, isto é, anula-a por vontade própria; assim como quem, 
Comportamento eleitoral nas eleições suplementares para prefeito no Brasil (2013-2015) Alvaro Augusto de Borba Barreto • Bruno Souza Garcia

apesar de ter escolhido um candidato, não consegue expressar de modo válido a sua escolha por algum tipo de incapacidade cognitiva própria ou estimulada por procedimentos de votação complexos, ambíguos ou confusos.

Os estudos reputam o voto nulo a essas duas modalidades: erro e protesto ou apatia. Os resultados alcançados por Silva (2013) apontam para baixos índices educacionais e de renda dos municípios, o que o aproxima do erro, mais do que do protesto. No que tange à anulação intencional, de modo semelhante ao que ocorre com o voto em branco, o pesquisador argumenta que ele pode ser ocasional, relativo à inconformidade com o conjunto de candidatos presentes em uma disputa, ou permanente, fruto da insatisfação com o sistema de voto (obrigatório, no caso brasileiro), com a circunstância política em que se processa o pleito ou decorrente de postura ideológica que não concorda com o sistema representativo. Estudos realizados durante e/ou sobre a ditadura civil-militar brasileira, como os de Soares (2001), Trindade e Cew (1978), Lamounier (1980), relacionaram-no à contestação política ao regime, notadamente na eleição de 1970.

O advento da urna eletrônica modificou os procedimentos de votação e fortaleceu as diferenças entre os votos em branco e nulo. Para distinguir o voto em branco da não votação - o que, se não fosse feito, deixaria o sistema em aberto e impediria novos eleitores de sufragar -, passou a existir a obrigação de manifestar a "não expressão" que tanto o caracteriza. Para atender essa necessidade, foi criada a tecla: "branco". Essa peculiaridade cria incentivos para a ocorrência desse voto, pois, conforme Nicolau (2015, p. 9), ele se tornou a mais simples opção para os eleitores.

No caso do nulo, ao inverso, efetivá-lo ficou mais complexo, não só pela ausência de uma tecla específica que o expresse, mas porque é necessário digitar número correspondente a candidato inexistente, ignorar a mensagem que vai trazer essa informação e apertar "confirma". Antes, bastava riscar a cédula, embora outras formas de manifestação fossem possíveis, pois, eram nulos, igual- 
Comportamento eleitoral nas eleições suplementares para prefeito no Brasil (2013-2015) Alvaro Augusto de Borba Barreto • Bruno Souza Garcia

mente, os votos que contivessem escritos ou elementos gráficos estranhos ao ato de votar (BRASIL.TSE, 2016h).

Também é possível considerar outra característica que pode ajudar a entender a situação em análise: ao se abster, o eleitor adota o mesmo comportamento para todos os cargos em disputa, o que não necessariamente ocorre quando o voto é invalidado. Existe a possibilidade de fazê-lo para um, e não para outro, assim como optar por formas diferentes de invalidação para cada posto, ou seja, votar em branco para " $x$ " e nulo para " $y$ ".

Diversas investigações já identificaram que o índice de invalidação para cargos proporcionais é mais elevado do que para majoritários. Power e Roberts (1995), por exemplo, destacam a estrutura da cédula e o voto preferencial como principais responsáveis por esta tendência.

Nicolau $(2004,2015)$ investiu nos desdobramentos da questão. Ao analisar a eleição de 1998, distinguiu tipos de voto inválido, considerou o eleitorado que votou em cédula de papel ou na urna eletrônica, bem como o IDH dos municípios e o cargo em disputa. Os resultados apontaram queda do voto em branco com o uso da urna eletrônica em todos os cargos, o que foi acompanhado pelo nulo apenas para postos de deputado. O mesmo não ocorreu naqueles definidos pelo sistema majoritário (senador, governador e presidente), em que houve aumento dos votos nulos. Consequentemente ocorre uma distinção entre essas duas modalidades de invalidação.

Em um primeiro estudo, Nicolau (2004, p. 17) aventou a hipótese de que os votos nulos tenham diminuído nas eleições proporcionais, pois se tornou mais fácil votar - pelas razões vistas anteriormente - e ocorreram menos erros. O mesmo não se deu nos cargos majoritários, tendo em vista que o procedimento na cédula de papel (assinalar uma cruz em um box ao lado dos nomes) era mais simples do que o agora exigido.

Em um segundo texto, Nicolau (2015, p. 18) formulou versão mais sofisticada dessa hipótese, em que outro aspecto do procedimento de votação ganhou centralidade. Ao contrário do que ocor- 
Comportamento eleitoral nas eleições suplementares para prefeito no Brasil (2013-2015) Alvaro Augusto de Borba Barreto • Bruno Souza Garcia

ria na cédula de papel, em que a sequência era definida livremente pelo eleitor, na urna eletrônica há uma ordem previamente estabelecida, à qual inevitavelmente é preciso se submeter, pois só se passa para a escolha seguinte ao completar a anterior, bem como a votação só se encerra quando ocorre o registro de manifestação para todos os cargos.

Não bastasse isso, a ordem começa pelos cargos legislativos para depois chegar aos do executivo, considerada pelo autor como contraintuitiva, assim como fator que contribui para a alta taxa de votos nulos. Isto porque o autor aponta que o eleitor supõe que presidente e governador, cargos que ele considera mais importantes sejam votados primeiro. Mas, ao digitar os números correspondentes, ele está sufragando para deputado. Ao chegar aos derradeiros, que imagina serem os legislativos - cuja opção para muitos é a anulação -, na realidade, vota em governador e presidente.

Em artigo escrito com Zucco, foi demonstrada a associação entre aumento do voto inválido para presidente e baixo IDH dos municípios, indicador de maior presença de eleitores com menos educação formal, o que permite destacar: "quando os eleitores não conseguem entender que a primeira votação não é para o presidente, eles também não entendem que a última votação é para o presidente" (ZUCCO, NICOLAU, 2016, p. 18).

Igualmente, os autores mostram que a hipótese explica outro efeito produzido pela urna eletrônica, classificado como um novo tipo de erro: o aumento no voto de legenda para deputado federal e estadual, especialmente no caso dos partidos que têm concorrente ao executivo. Como a ordem de votação está de "cabeça para baixo", ao supor que esteja votando nos cargos executivos, o eleitor consagra a legenda, cujo número é idêntico ao dos candidatos a presidente e a governador.

Se assim se confirma a existência de equívoco no voto para os primeiros cargos na urna eletrônica, permanece sem plena demonstração a parte da assertiva que explica o crescimento da nu- 
Comportamento eleitoral nas eleições suplementares para prefeito no Brasil (2013-2015) Alvaro Augusto de Borba Barreto • Bruno Souza Garcia

lidade para governador e presidente, os últimos a serem votados. Afinal, o eleitor poderia simplesmente votar em branco. No texto em que a formulou, Nicolau (2015) não apresenta evidências que a comprovem ou a invalidem. Já o artigo que ele escreveu juntamente com Zucco (2016) não distingue os tipos de voto inválido, de modo a não esgotar a hipótese.

A intenção deste texto é, seguindo esse escopo, tentar explicar a maior redução dos votos nulos em comparação aos em branco nas eleições suplementares e, ao mesmo tempo, produzir evidências que ajudem indiretamente a testar a hipótese proposta por Nicolau (2015).

Argumenta-se que nos pleitos suplementares não se verificam dois fatores que contribuem para o aumento do voto nulo por erro nos cargos majoritários na urna eletrônica. O primeiro é a maior simplicidade da escolha, restrita a um cargo. A segunda, a ausência de qualquer efeito produzido pela sequência de votação, já que ela inexiste.

Sem esses elementos, menos votos nulos ocorrem por erro. Logo, ele se reduz em comparação à eleição ordinária e os índices registrados correspondem principalmente ao eleitor que anula intencionalmente o sufrágio. Isto explicaria porque houve a redução mais intensa do voto nulo em comparação ao em branco, bem como vincula aquele registrado mais fortemente ao protesto/apatia.

Mais uma vez, sem que os eleitores tenham sido ouvidos, a alternativa é trabalhar com dados agregados. A primeira possibilidade é testar o voto nulo por erro, o que pode ser realizado ao relacionar a sua variação com o IDHM-Educação ${ }^{13}$. Afinal, se a maior anulação está associada ao baixo nível de escolaridade nos municípios, como vários estudos já o demonstraram, é de se esperar que a redução mais discreta (ou até o aumento) dessa taxa seja registrada nas localidades de menor IDHM-Educação, como indicador da persistência do erro.

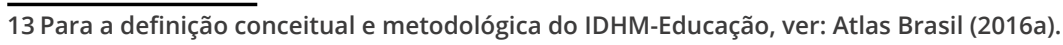


Comportamento eleitoral nas eleições suplementares para prefeito no Brasil (2013-2015) Alvaro Augusto de Borba Barreto • Bruno Souza Garcia

Tabela 5 - Voto nulo na eleição suplementar (2013-2015) em comparação à anulada (2012) conforme IDHM-Educação, em percentual ${ }^{14}$

\begin{tabular}{lrrr}
\hline NULO & & IDHM-EDUCAÇÃO 2010 \\
& ALTO & MÉDIO & BAIXO \\
\hline Aumentou & 37,5 & 25,6 & 11,5 \\
Diminuiu & 62,5 & 74,4 & 88,5 \\
TOTAL & $(8)$ & $(43)$ & $(61)$ \\
\hline
\end{tabular}

Fonte: BRASIL. TSE (2016, 2016g); G1 (2016); Atlas Brasil (2016)

Os dados mostram que quanto mais alto o patamar no IDHMEducação, mais elevado o contingente de pleitos em que o voto nulo aumentou. Inversamente, quanto mais baixa a classificação, maior é o percentual de eleições em que houve redução nos votos nulos.

Tais informações confirmam a expectativa da hipótese de Nicolau (2015), ao mesmo tempo em que contrariam a especulação do parágrafo anterior. A simplificação do processo de votação na eleição suplementar produziu menos votos nulos naqueles municípios com eleitores de menor educação formal, os mais sensíveis à anulação por erro diante das exigências de votação da urna eletrônica.

A segunda possibilidade é relacionar as eleições suplementares com aquelas em que houve $2^{\circ}$ turno, já que as exigências apresentadas ao eleitor são as mesmas: escolher um cargo, sem qualquer efeito da sequência de votação. A comparação foi realizada com 241 eleições ordinárias para prefeito, ocorridas entre 1996 e 2016, todas com uso de urna eletrônica.

14 Dois esclarecimentos: a) um município, instalado após o Censo 2010, não foi incluído, pois não há dados; b) o parâmetro de classificação do IDHM-Educação 2010 é o apresentado pelo Atlas Brasil: baixo (até 0,599), médio $(0,600-0,699)$ e alto $(0,700$ 0,799). Nenhum dos municípios analisados está no patamar muito alto $(0,800-1)$. 
Comportamento eleitoral nas eleições suplementares para prefeito no Brasil (2013-2015) Alvaro Augusto de Borba Barreto • Bruno Souza Garcia

Tabela 6 - Voto em branco e nulo na eleição suplementar (2013-2015) em comparação à votação anulada (2012) e no $2^{\circ}$ turno do pleito municipal em relação ao $1^{\circ}(1996-2016)$, em percentual

\begin{tabular}{lrr|rr}
\hline RESULTADO & SUPLEMENTAR & \multicolumn{2}{c}{ MUNICIPAIS } \\
& EM BRANCO & NULO & EM BRANCO & NULO \\
\hline Aumentou & 41,6 & 18,6 & 8,7 & 17,3 \\
Diminuiu & 58,4 & 81,4 & 91,3 & 81,7 \\
TOTAL & $(113)$ & $(113)$ & $(241)$ & $(241)$ \\
\hline
\end{tabular}

Fonte: BRASIL. TSE (2016, 2016e, 2016g); G1 (2016)

Para facilitar a comparação, a Tabela 6 repete os resultados das eleições suplementares, expostos na Tabela 4. Ela mostra que o contingente de redução dos votos nulos é praticamente igual nos dois tipos de disputas $(81,7 \%$ e $81,4 \%)$, o que não ocorre com os votos em branco, cuja diminuição é de $91,3 \%$ nas municipais e de $58,4 \%$ nas suplementares.

Logo, assim como a primeira análise, ela indica que há redução dos votos nulos em pleitos cujo procedimento de votação é mais simples. Pode-se supor que a queda se refira a menos anulação produzida por erro. E, consequentemente, que os índices registrados correspondam mais a eleitores que o fizeram intencionalmente. Ainda mais relevante: os resultados são compatíveis com o fundamento da hipótese de Nicolau (2015), ou seja, quando há mais cargos em disputa e atua a ordem de votação contraintuitiva, o percentual de nulo cresce para cargos majoritários ${ }^{15}$.

Todavia, parte da questão persiste: nas eleições suplementares, por que houve menos casos em que os votos em branco se reduziram? O estudo de Nicolau (2015) e os dados relativos aos pleitos municipais em que houve $2^{\circ}$ turno apontam para decréscimo mais intenso dos votos em branco, de modo que o comportamento desviante é o registrado nas eleições suplementares.

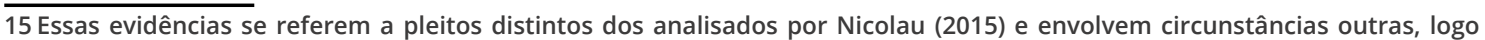
não permitem comprovar a hipótese do autor, mas fornecem subsídios que corroboram sua fundamentação epistemológica. 
Comportamento eleitoral nas eleições suplementares para prefeito no Brasil (2013-2015) Alvaro Augusto de Borba Barreto • Bruno Souza Garcia

Pode-se indicar que, nelas, ocorra comportamento distinto em comparação a tais pleitos - e também em relação ao voto nulo. O eleitor que compareceu às urnas para cumprir uma obrigação legal, mas que não estava interessado na eleição, optou por essa que é a alternativa de mais fácil execução. Assim, o índice de eleições em que ele se reduziu em relação à disputa original foi menor comparado ao dos nulos. A situação específica é resumida no dito de Amaral e Cunha (2010, p. 89): voto em branco é de quem cala; nulo, de quem fala protestando.

Argumenta-se, ainda, que anteriormente foi possível aproximar eleições suplementares e aquelas com $2^{\circ}$ turno nas tendências de aumento da abstenção e de redução dos votos inválidos. Todavia, ao distinguir os tipos de invalidação, algumas peculiaridades contribuem para que, sem contrariar essas semelhanças, manifestem-se diferenças. Elas se dão no âmbito exclusivo do voto em branco, pois as evidências indicam que há similitude no caso do voto nulo. Tais diferenças são de escala populacional, de intervalo para o retorno às urnas e de previsibilidade, afinal, todas as eleições suplementares em análise ocorreram em municípios com menos de 200 mil eleitores, meses ou mais de ano após a anulação do pleito ordinário, enquanto as municipais em apreço obrigatoriamente se dão em localidades com mais de 200 mil eleitores, estão previamente programadas e são promovidas no mesmo mês da $1^{a}$ votação, como novo e decisivo turno da mesma disputa.

\section{Considerações finais}

Eleições suplementares são um novo pleito, com a retomada de todas as etapas do processo eleitoral. Na mesma medida, supõem a possibilidade de novos comportamentos do eleitor. Para tal perspectiva contribuem as suas peculiaridades e as vinculações com a eleição ordinária, que não podem ser desconhecidas: ocorre após a invalidação da anterior, o que arrastou para a nulidade a decisão tomada pelo eleitorado; confere mandato que será mais 
Comportamento eleitoral nas eleições suplementares para prefeito no Brasil (2013-2015) Alvaro Augusto de Borba Barreto • Bruno Souza Garcia

curto ao vencedor, destinado a complementar o original, cujo titular não chegou a tomar posse ou, se o fez, teve a gestão interrompida por decisão da Justiça Eleitoral.

O olhar do artigo, dirigido ao comportamento do eleitor nas 113 eleições suplementares para prefeito, realizadas entre 20132015, comprovaram esses pressupostos: $93,8 \%$ delas tiveram mais abstenção; $72,6 \%$ apresentaram redução do voto inválido. Esse comportamento é semelhante àquele apresentado nas eleições com $2^{\circ}$ turno. A interpretação apresentada vinculou mais ausência do eleitorado a fatores atitudinais, tendo utilizado a redução na abstenção registrada na maioria desses mesmos municípios em 2016, mas superior à de 2012, como demonstração da excepcionalidade da decisão do eleitor na eleição suplementar.

No que tange à redução da invalidação do voto, considerou-se que o eleitor que superou os custos de retornar às urnas, tinha mais possibilidade de escolher um dos candidatos. Desse modo, a decisão mais fundamental para o comportamento do eleitor é ir ou não votar.

A pesquisa investiu na distinção entre os dois tipos de voto inválido e os resultados mostraram haver diferença entre eles. Em ambos predominou a redução na eleição suplementar em comparação ao pleito ordinário, mas os votos em branco diminuíram em $58,4 \%$ dos casos, e os nulos em $81,4 \%$.

Seguindo a hipótese formulada por Nicolau (2015), a explicação para a mais intensa redução dos votos nulos considerou que a maior simplicidade do procedimento de votação na eleição suplementar contribuiu para eliminar a principal fonte das anulações, aquelas provenientes de erro. Concomitantemente, ampliou aquela proveniente de um eleitor inconformado ou apático em relação ao pleito. Nessa trilha, ponderou que a redução menos intensa dos votos em branco decorre de um eleitor tão pouco motivado com a eleição suplementar e desinteressado face à oferta eleitoral que também não estava disposto a cumprir os requisitos mais complexos para votar nulo, razão pela qual seguiu a opção mais simples, o voto em branco. 
Comportamento eleitoral nas eleições suplementares para prefeito no Brasil (2013-2015) Alvaro Augusto de Borba Barreto • Bruno Souza Garcia

\section{Referências}

AMARAL, Roberto; CUNHA, Sérgio Sérvulo da. Manual das eleições. 4 ed. São Paulo: Saraiva, 2010.

ANSOLABEHERE, Stephen; STEWART III, Charles. Residual votes attributable to technology. The Journal of Politics, v. 67, n. 2, p. 365-389, 2005.

ATLAS BRASIL. Consulta. IDHM-Educação 2010. 2016. Disponível em: http://www.atlasbrasil.org.br/2013/pt/consulta/. Acesso em: 31 out. 2016.

ATLAS BRASIL. Metodologia - IDHM Educação. 2016a. Disponível em: http://www.atlasbrasil.org.br/2013/pt/o_atlas/metodologia/ idhm_educacao/. Acesso em: 31 out. 2016.

BLAIS, André; GIDENGIL, Elisabeth; NEVITTE, Neil. Where does turnout decline come from? European Journal of Political Research, n. 43, p. 221-236, 2004.

BORBA, Julian. As bases sociais e atitudinais da alienação eleitoral no Brasil. Revista Debates, v. 2, n. 2, p. 134-157, 2008.

BRASIL. Código Eleitoral (Lei 4.737, de 15 jul. 1965). Disponível em: http://www.planalto.gov.br/ccivil_03/leis/14737.htm. Acesso em: 31 out. 2016.

BRASIL. Tribunal Superior Eleitoral. Eleições anteriores (eleições 1994 a 2014). 2016e. Disponível em: http://www.tse.jus.br/eleicoes/eleicoes-anteriores/eleicoes-anteriores. Acesso em: 31 out. 2016.

BRASIL. Tribunal Superior Eleitoral. Eleições municipais 2016 - $1^{\circ}$ turno. Divulgação de resultados de eleições. 2016d. Disponível em: 
Comportamento eleitoral nas eleições suplementares para prefeito no Brasil (2013-2015) Alvaro Augusto de Borba Barreto • Bruno Souza Garcia

http://divulga.tse.jus.br/oficial/index.html. Acesso em: 31 out. 2016.

BRASIL. Tribunal Superior Eleitoral. Eleições suplementares. Calendário das eleições suplementares 2015. 2016a. Disponível em: http://www.tse.jus.br/eleicoes/eleicoes-suplementares/calendario-das-eleicoes-suplementares-2015. Acesso em: 31 out. 2016. BRASIL. Tribunal Superior Eleitoral. Eleições suplementares. Calendário das eleições suplementares 2014. 2016b. Disponível em: http://www.tse.jus.br/eleicoes/eleicoes-suplementares/calendario-das-eleicoes-suplementares-2014. Acesso em: 31 out. 2016.

BRASIL. Tribunal Superior Eleitoral. Eleições suplementares. Calendário das eleições suplementares 2013. 2016c. Disponível em: http://www.tse.jus.br/eleicoes/eleicoes-suplementares/calendario-das-eleicoes-suplementares-2013. Acesso em: 31 out. 2016. BRASIL. Tribunal Superior Eleitoral. Estatísticas TSE - eleições 2012. 2016. Disponível em: http://www.tse.jus.br/hotSites/estatistica2012/index.html. Acesso em: 31 out. 2016.

BRASIL. Tribunal Superior Eleitoral. Glossário Eleitoral.

Abstenção eleitoral. 2016f. Disponível em: http://www.tse.jus.br/ eleitor/glossario/termos-iniciados-com-a-letra-a\#abstencao-eleitoral. Acesso em: 31 out. 2016.

BRASIL. Tribunal Superior Eleitoral. Glossário eleitoral. Voto nulo. 2016h. Disponível em: http://www.tse.jus.br/eleitor/glossario/termos-iniciados-com-a-letra-v\#voto-nulo. Acesso em: 31 out. 2016.

BRASIL. Tribunal Superior Eleitoral. Série urna eletrônica: biometria garante registro único de cada eleitor. 21 jan. 2016. Disponível em: http://www.tse.jus.br/imprensa/noticias-tse/2016/ Janeiro/serie-urna-eletronica-biometria-garante-registro-unico-de-cada-eleitor. Acesso em: 31 out. 2016. 
BRASIL. Tribunal Superior Eleitoral. Votos dos candidatos com registro indeferido no $1^{\circ}$ turno das eleições de 2012. $2016 \mathrm{~g}$. Disponível em: http://www.tse.jus.br/arquivos/votos-dos-candidatos-com-registro-indeferido/view. Acesso em: 31 out. 2016.

CALVO, Ernesto; ESCOLAR, Marcelo; POMARES, Julia. Ballot design and split ticket voting in multiparty systems: experimental evidence on information effects and vote choice. Electoral Studies, v. 28, n. 2, p. 218-231, 2009.

COELHO, Margarete. A democracia na encruzilhada: reflexões acerca da legitimidade democrática da Justiça Eleitoral brasileira para a cassação de mandatos eletivos. São Leopoldo, 2014. Dissertação (Mestrado em Direito) - Universidade do Vale do Rio dos Sinos, 2014.

COSTA, Homero de Oliveira. Democracia e representação política no Brasil: uma análise das eleições presidenciais (1989-2002). Porto Alegre: Sulina; Natal: UFRN, 2007.

CRESPO, Ralph. Eleições suplementares no Brasil: os casos decorrentes das anulações do pleito de 2012. Campos de Goytacazes, 2017. Dissertação (Mestrado em Sociologia Política) Universidade Estadual do Norte Fluminense, 2017.

DEE, Thomas. Technology and voter intent: evidence from de California recall election. The Review of Economics of Statistics, v. 89, n. 4, p. 674-683, 2007.

DRISCOLL, Amanda; NELSON, Michael. Ignorance or opposition? Blank and spoiled votes in low-information, highly politicized environments. Political Research Quaterly, v. 67, n. 3, p. 547-561, 2014.

EBC (EMPRESA BRASILEIRA DE COMUNICAÇÃO). Eleição para prefeito em Criciúma não desperta interesse do eleitor. 2 
Comportamento eleitoral nas eleições suplementares para prefeito no Brasil (2013-2015) Alvaro Augusto de Borba Barreto • Bruno Souza Garcia

mar. 2013. Disponível em: http://www.ebc.com.br/noticias/politica/2013/03/eleicao-para-prefeito-em-criciuma-nao-desperta-interesse-dos-eleitores. Acesso em: 31 out. 2016.

ELKINS, Zachary. Quem iria votar? Conhecendo as consequências do voto obrigatório no Brasil. Opinião Pública, v.6, n. 1, p. 109136, 2000.

ESPÍNDOLA, Ruy. Justiça Eleitoral contramajoritária e soberania popular: a democrática vontade das urnas e a autocrática vontade judicial que a nulifica. Unisul de Fato e de Direito, v.7, n. 3, p. 97-118, 2013.

FERRAZ JÚNIOR, Vitor E. M. Poder judiciário e competição política no Brasil: uma análise das decisões do TSE e do STF sobre as regras eleitorais. São Paulo, 2008. Tese (Doutorado em Ciências Sociais) - Pontifícia Universidade Católica de São Paulo, 2008.

FIGUEIREDO, Marcus. O voto obrigatório. In: LAMOUNIER, Bolívar et al. Cem anos de eleições presidenciais. São Paulo: Idesp, 1990. p. 39-46.

FLEISCHER, David. As eleições municipais no Brasil: uma análise comparativa (1982-2000). Opinião Pública, v. 8, n. 1, p. 80-105, 2002.

FLORENTINO, Renata. Cadê o voto que estava aqui? Relações entre migração, transferência de título e abstenção eleitoral. Urbanidades, v. 5, n. 1, 2007. Disponível em: http://www.urbanidades.unb.br/artigo_3.html. Acesso em: 30 mar. 2008.

FRANKLIN, Mark N. Electoral participation In: LEDUC, Lawrence; NIEMI, Richard; NORRIS, Pippa. (ed.). Comparing democracies. London: Sage, 1996. p. 216-235. 
Comportamento eleitoral nas eleições suplementares para prefeito no Brasil (2013-2015) Alvaro Augusto de Borba Barreto • Bruno Souza Garcia

FRANKLIN, Mark N.; LYONS, Patrick; MARSH, Michael.

Generational basis of turnout decline in established democracies.

Acta Politica, v. 39, p.115-151, 2004.

FREIRE, André. Desempenho da democracia e reformas políticas - o caso português em perspectiva comparada. Sociologia, problemas e práticas, n. 43, p. 133-160, 2003.

FREIRE, André; MAGALHÃES, Pedro. A abstenção eleitoral em Portugal. Lisboa: Imprensa de Ciências Sociais, 2002.

FUJIWARA, Thomas. Voting technology, political responsiveness and infant health: evidence from Brazil. Econometrica, v. 83, n. 2, p. 423-464, 2015.

GALLI, Joel Eliseu. A suspeita democrática observada a partir da judicialização da megapolítica: estudo dos estímulos à expansão intervencionista da Justiça Eleitoral a partir da análise de julgamentos do TRE-SC no período 2004-2012. Florianópolis, 2014. Dissertação (Mestrado em Sociologia Política) - Universidade Federal de Santa Catarina, 2014.

GALLEGO, Aina. Where else does turnout decline come from? Education, age, generation and period effects in three European countries. Scandinavian Political Studies, v. 32, n. 1, p. 23-44, 2009.

GARCIA, Bruno Souza. Eleições suplementares para prefeito (2013-2015): do perfil socioeconômico dos municípios ao comportamento eleitoral e partidário. Pelotas, 2016. Dissertação (Mestrado em Ciência Política) - Universidade Federal de Pelotas, 2016.

GEYS, Benny. Explaining voter turnout: a review of aggregate-level research. Electoral Studies, v. 25, n. 4, p. 637-663, 2006. 
GULISANO, Adriano; DARWICH, Isadora. Abstentionism, blank vote and invalid ballot papers evidences from Brazil and E.U. 11 jan. 2015. Disponível em: https://ssrn.com/abstract=2548161. Acesso em: 31 out. 2016.

G1. Eleições 2012. 2016. Disponível em: http://g1.globo.com/politica/eleicoes/2012/. Acesso em: 31 out. 2016.

HIDALGO, F. Daniel. Digital democratization: suffrage expansion and the decline of political machines in Brazil. Paper. Berkeley: UC. 2010. Disponível em: http://www.politics.as.nyu. edu/docs/IO/17524/hidalgo.pdf. Acesso: 31 out. 2016.

HILL, Lisa; YOUNG, Sally. Protest or error? Informal voting and compulsory voting. Australian Journal of Political Science, v. 42, n. 3, p. 515-521, 2007.

JUSTEL, Manuel. La abstención electoral en España - 1977-1993. Madrid: Centro de Investigaciones Sociológica, 1995.

KIMBALL, David; KROPF, Martha. Voting technology, ballot measures, and residual votes. American Politics Research, v. 36, n. 4, p. 479-509, 2008.

KUNTZ, Jamile. Eleições suplementares e desincompatibilização: a tentativa jurisprudencial de compatibilizar os institutos. Revista Brasileira de Direito Eleitoral, v. 3, n. 4, p. 73-92, 2011.

LAMOUNIER, Bolívar. O voto em São Paulo, 1970-1978. In: LAMOUNIER, Bolívar. (org.). Voto de desconfiança: eleições e mudança política no Brasil 1970-1979. São Paulo: Vozes, 1980.

LAVAREDA, Antônio. A democracia nas urnas - o processo partidário eleitoral brasileiro. Rio de Janeiro: luperj; Rio Fundo, 1991. LIMA, Sídia. $\mathbf{O}$ ativismo judicial e o judiciário eleitoral: um estudo da atividade legislativa do Tribunal Superior Eleitoral. Recife, 
Comportamento eleitoral nas eleições suplementares para prefeito no Brasil (2013-2015) Alvaro Augusto de Borba Barreto • Bruno Souza Garcia

2011. Tese (Doutorado em Ciência Política) - Universidade Federal de Pernambuco, 2011.

LIMA JÚNIOR, Olavo Brasil de. Alienação eleitoral e seus determinantes - nota de pesquisa. Revista Brasileira de Ciências Sociais, ano 5, n. 14, p. 68-72, 1990.

LIMA JÚNIOR, Olavo Brasil de. Democracia e instituições políticas no Brasil dos anos 80. São Paulo: Loyola, 1993.

LIMA JÚNIOR, Olavo Brasil de; ANASTASIA, Fatima. A participação eleitoral: a ampliação do mercado, indicadores de participação e distorções do sistema de representação. Teoria \& Sociedade, n. 4, p. 33-104, 1999.

MARCHETTI, Vitor. Competição eleitoral e controle das candidaturas: uma análise das decisões do TSE. Cadernos Adenauer, v. 15, n. 1 p. 93-115, 2014.

MATTOS NETO, Mario. Democracia e participação eleitoral no Brasil. São Paulo, 1997. Dissertação (Mestrado em Ciência Política) - Universidade de São Paulo, 1997.

MCALLISTER, Ian; MAKKAI, Toni. Institutions, society or protest? Explaining invalid votes in australian elections. Electoral Studies, v. 12, n. 1, p. 23-40, 1993.

MIGUEL, Luis Felipe. A democracia domesticada: bases antidemocráticas do pensamento democrático contemporâneo. Dados, v. 45, n. 3, p. 483-511, 2002.

MORAES, Murilo Ferreira de. Voting technology and political competition: lessons from overlapping political races in Brazil. São Paulo, 2012. Dissertação (Mestrado em Economia) Universidade de São Paulo, 2012. 
Comportamento eleitoral nas eleições suplementares para prefeito no Brasil (2013-2015) Alvaro Augusto de Borba Barreto • Bruno Souza Garcia

NICOLAU, Jairo. A participação eleitoral no Brasil. In: VIANNA, Luiz Werneck (org.). A Democracia e os três poderes no Brasil. Belo Horizonte: UFMG, 2002, p. 255-295.

NICOLAU, Jairo. A participação eleitoral: evidências sobre o caso brasileiro. VIII Congresso Luso-brasileiro de Ciências Sociais. Coimbra, 2004.

NICOLAU, Jairo. Impact of electronic voting machines on blank votes and null votes in Brazilian elections in 1998. Brazilian Political Science Review, v. 9, n. 3, p. 3-20, 2015.

NOGUEIRA, Ary Jorge Aguiar. A Judicialização da competição eleitoral municipal no Brasil: um estudo sobre as eleições suplementares de 2004 a 2018. Rio de Janeiro, 2019. Dissertação (Mestrado em Direito) - Universidade Federal do Estado do Rio de Janeiro, 2019.

NORRIS, Pippa. Do institutions matter? The consequences of electoral reform for political participation. In: CRIGLER, Ann; JUST, Marion; MCCAFFERY, Edward (ed.). Rethinking the vote. Oxford University Press, 2003, p. 133-148.

PEREA, Eva Anduiza. Indivíduos o sistemas? Las razones de la abstención en Europa Occidental. Madrid: CIS, 1999.

PORTO, Walter Costa. Dicionário do voto. São Paulo: Giordano, 1995.

POWER, Timothy; GARAND, James. Determinants of invalid voting in Latin America. Electoral Studies, v. 26, n. 2, p. 432-444, 2007.

POWER, Timothy; ROBERTS, J. Timmons. Compulsory voting, invalid ballots and abstention in Brazil. Political Research

Quarterly, v. 48, n. 3, p. 795-826, 1995. 
Comportamento eleitoral nas eleições suplementares para prefeito no Brasil (2013-2015) Alvaro Augusto de Borba Barreto • Bruno Souza Garcia

REIS, Antônio C. Alkmin. A participação eleitoral e seus correlatos socioeconômicos. In: LIMA JúNIOR, Olavo Brasil de (org.). Sistema eleitoral: teoria e prática. Rio de Janeiro: Rio Fundo; luperj, 1991.

REYNOLDS, Andrew; STEENBERGEN, Marco. How the world votes: the political consequences of ballot design, innovation and manipulation. Electoral Studies, v. 25, n. 3, p. 570-598, 2006.

RIBEIRO, Ednaldo Aparecido; BORBA, Julian; SILVA, Rafael da. Comparecimento eleitoral na América Latina: uma análise multinível comparada. Revista de Sociologia e Política, v. 23, n. 54, p. 91-108, 2015.

SALGADO, Eneida. Princípios constitucionais estruturantes do Direito Eleitoral. Curitiba, 2010. Tese (Doutorado em Direito) Universidade Federal do Paraná, 2010.

SANTOS, Wanderley Guilherme dos. Crise e castigo. Rio de Janeiro: Vértice, 1987.

SILVA, Rafael da. Alienação eleitoral: um estudo comparado das bases sociais e atitudinais. Revista Andina de Estudios Políticos, v. 3, n. 1, 109-133, 2013.

SILVA, Rafael da. Comportamento eleitoral na América Latina e no Brasil: em busca dos determinantes das abstenções, votos brancos e votos nulos. Florianópolis, 2016. Tese (Doutorado em Sociologia e Política), Universidade Federal de Santa Catarina, 2016.

SILVA, Rafael da et al. Votos brancos e nulos no Brasil: bases cognitivas e atitudinais. Teoria e Pesquisa, v. 23, n. 2, p. 64-81, 2014. SOARES, Glaucio Ary Dillon. A democracia interrompida. Rio de Janeiro: FGV, 2001. 
Comportamento eleitoral nas eleições suplementares para prefeito no Brasil (2013-2015) Alvaro Augusto de Borba Barreto • Bruno Souza Garcia

TRINDADE, Hélgio; CEW, Judson de. Confrontação política e decisão eleitoral: as eleições municipais de 1976 em Caxias do Sul. In: REIS, Fábio Wanderley (org.). Os partidos e o regime: a lógica do processo eleitoral brasileiro. São Paulo: Símbolo, 1978.

VITULLO, Gabriel Eduardo. Participación electoral, comportamiento político y desestructuracíon social en Argentina y Brasil In: LEVY, Betina (org.). Crisis y conflicto en el capitalismo latinoamericano: lecturas políticas. Buenos Aires: Clacso, 2002, p. 223-247.

WATTENBERG, Martin. Is voting for young people? New York: Pearson Longman, 2006.

ZALAMENA, Juliana. Judicialização, competição política local e eleições municipais no Rio Grande do Sul. Porto Alegre, 2013. Dissertação (Mestrado em Ciência Política) - Universidade Federal do Rio Grande do Sul, 2013.

ZILIO, Rodrigo. Renovação da eleição e participação de quem deu causa à nulidade. Revista do TRE/RS, n. 11, p. 22: 23-47, 2006.

ZUCCO, Cesar; NICOLAU, Jairo. Trading old errors for new errors? The impact of electronic voting technology on party label votes in Brazil. Electoral Studies, v. 43, p. 10-20, 2016. 